\title{
IMPLEMENTASI PROGRAM SOSIALISASI PENGOLAHAN DAN PEMASARAN PRODUK OLAHAN IKAN AIR TAWAR DALAM UPAYA MENINGKATKAN PENDAPATAN MASYARAKAT TERHADAP PEREKONOMIAN DI DESA TAPEN KECAMATAN TAPEN KABUPATEN BONDOWOSO
}

\section{IMPLEMENTATION OF SOCIALIZATION OF PROCESSING AND MARKETING OF FRESH WATER FISH PRODUCTS IN EFFORTS TO INCREASE COMMUNITY INCOME ON THE ECONOMY IN TAPEN, BONDOWOSO}

\section{Ratna Aryu Ningrum ${ }^{1}$, Kurnia Nisa Kinasih ${ }^{2}$ Daiva Ilyaning Asrin ${ }^{3}$, Andini Avita $\mathrm{Ayu}^{4}$, Erina Devi Yuniara Sari ${ }^{5}$, Nur Mariam Kusuma ${ }^{6}$, Jasmina Vidi Quamilla ${ }^{7}$, M. Gandul Atik Yuliani ${ }^{8}$.}

${ }^{1}$ Program Studi Sosiologi, Fakultas Ilmu Sosial dan Politik, ${ }^{2}$ Program Studi Kedokteran Hewan, Fakultas Kedokteran Hewan, ${ }^{3}$ Program Studi Akuakultur, Fakultas Perikanan dan Kelautan, ${ }^{4}$ Program Studi Akuakultur, Fakultas Perikanan dan Kelautan, ${ }^{5}$ Program Studi Kedokteran Hewan, Fakultas Kedokteran Hewan, ${ }^{6}$ Program Studi Kedokteran Hewan, Fakultas Kedokteran Hewan, ${ }^{7}$ Program Studi Kesehatan Masyarakat, Fakultas Kesehatan Masyarakat, ${ }^{8}$ Program Studi Kedokteran Hewan, Fakultas Kedokteran Hewan Universitas Airlangga. email: ratna.aryu.ningrum2018@fisip.unair.ac.id

\begin{abstract}
.
The freshwater fishery sector is one of the potentials possessed by the village of Tapen due to its location near the river and the Sampean Baru dam, which is the largest river in Bondowoso Regency. However, the income of the people with the livelihood of freshwater fish fishermen in Tapen Village is not optimal because the community does not understand how to process and market processed freshwater fish products in order to increase the selling value of fish. Efforts to increase community income through the fisheries sector carried out by the $60 \mathrm{KKN}$ BBM Uniar period eke-63 are socialization of processing and marketing of processed freshwater fish products. The activity was carried out with a presentation method regarding the processing and marketing of processed freshwater fish products as well as a demonstration on the process of making processed freshwater fish products in the form of catfish dumplings and tilapia nuggets. The socialization participants were PKK women, village cadres, fishermen's wives, and prospective entrepreneurs from the village of Tapen. In addition, the socialization regarding the marketing of processed freshwater fish products was also carried out using the online method using the Whatsapp group media.

Keywors: Marketing, Processed Freshwater Fish Product, Processing, Socialization
\end{abstract}

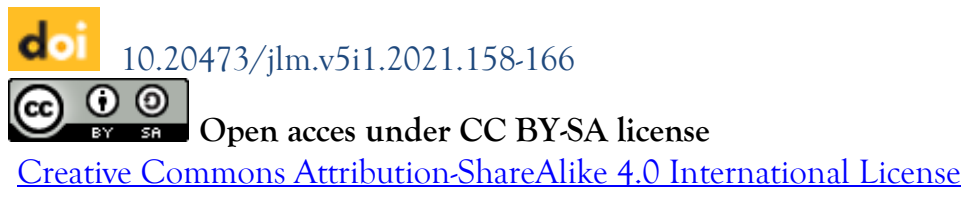




\begin{abstract}
Abstrak
Sektor perikanan air tawar merupakan salah satu potensi yang dimiliki oleh desa Tapen disebabkan letaknya yang berada di dekat sungai dan bendungan Sampean Baru yang merupakan sungai terbesar yang berada di Kabupaten Bondowoso. Namun, pendapatan masyarakat dengan mata pencaharian nelayan ikan air tawar di Desa Tapen belum maksimal karena masyarakat kurang memahami cara mengolah dan memasarkan produk olahan ikan air tawar guna meningkatkan nilai jual ikan. Upaya untuk meningkatkan pendapatan masyarakat melalui sektor perikanan yang dilakukan oleh kelompok 60 KKN BBM Uniar periode ke-63 adalah dengan Sosialisasi Pengolahan dan Pemasaran Produk Olahan Ikan Air Tawar. Kegiatan yang dilakukan dengan metode presentasi mengenai pengolahan dan pemasaran produk olahan ikan air tawar serta demonstrasi mengenai proses pembuatan produk olahan ikan air tawar yang berupa siomay ikan lele dan nugget ikan nila. Peserta sosialisasi adalah ibuibu PKK, kader desa, istri nelayan, serta calon pengusaha yang berasal dari desa Tapen. Selain itu sosialisasi mengenai pemasaran produk olahan ikan air tawar juga dilakukan dengan metode daring menggunakan media grup Whatsapp.
\end{abstract}

Kata Kunci: Pemasaran, Pengolahan, Produk Olahan Ikan Air Tawar, Sosialisasi

\title{
PENDAHULUAN
}

Kuliah Kerja Nyata (KKN) yang diselenggarakan oleh pihak Universitas Airlangga merupakan sarana bagi mahasiswa untuk melatih jiwa kepemimpinan dalam suatu kelompok di setiap individunya, kemampuan bekerja sama, beradu argumen dan tanggung jawab dalam melaksanakan kegiatan untuk mengabdi pada masyarakat. Selain itu, Kuliah Kerja Nyata juga dapat meningkatkan jiwa sosial dan kepekaan terhadap masyarakat karena mahasiswa dituntut untuk terjun langsung ke masyarakat guna membaur dan merasakan apa yang masyarakat rasakan setiap harinya. Dengan hal ini, mahasiswa memenuhi salah satu poin dari Tri Dharma Perguruan Tinggi mengenai Pengabdian Masyarakat.

Pelaksanaan KKN-BBM Periode ke-63 Kelompok 60 ini bertempat di desa Tapen. Desa Tapen merupakan salah satu desa yang secara administratif termasuk ke dalam Kecamatan Tapen, Kabupaten Bondowoso. Desa ini terdiri atas lima dusun yaitu Dusun Jatian, Dusun Posong, Dusun Krajan, Dusun Bunutan, dan Dusun Jesabe. Desa Tapen dikenal luas sebagai salah satu sentra kesenian Singo Baron atau Singo Ulung. Desa Tapen saat ini juga berusaha untuk memajukan potensi wisatanya melalui pembangunan Tapen Thematic Park yang dikenal masyarakat dengan nama Wisata Bukit Luwih. Masyarakat Desa Tapen sebagian besar juga bekerja di sektor pertanian dengan lahan pertanian yang sangat luas dan air yang cukup. Selain pariwisata dan pertanian, Desa Tapen juga memiliki potensi di sektor perikanan. Hal ini disebabkan letaknya yang berada di dekat Sungai atau Bendungan Sampean Baru dan juga berdekatan dengan Danau Sampean Baru. Potensi ikan yang beragam memberikan efek positif bagi sebagian masyarakat di sekitarnya dengan memanfaatkannya untuk mencari ikan. Umumnya kegiatan mencari ikan tersebut bukanlah pekerjaan utama, tetapi hanyalah pekerjaan sampingan bagi masyarakat di Desa Tapen. Berdasarkan pengamatan di lapangan dan wawancara terhadap masyarakat sekitar, bahwasanya terdapat beberapa jenis ikan antara lain Cyprinus carpio L (ikan Tombro), Barbodes binotatus (ikan Wader), Oreochromis niloticus (ikan Nila), Clarias (ikan Lele) dan masih banyak jenis ikan air tawar yang ada di sungai dan danau bendungan Sampean Baru..

Ikan dan produk olahannya berperan penting sebagai sumber nutrisi bagi manusia yaitu sumber protein, asam lemak, vitamin dan unsur-unsur mikro lainnya (Belitz et al., 2009). Besarnya manfaat dari ikan dan produk olahannya juga dirasakan 
oleh masyarakat di Desa Tapen. Potensi sumberdaya ikan di Desa Tapen memberikan manfaat secara ekonomi dalam bentuk ikan segar dan memberikan manfaat secara kesehatan dengan diolah sendiri menjadi masakan ibu rumah tangga ketika tangkapan ikan melimpah. Mayoritas penduduk Desa Tapen tidak mengolah hasil tangkapan ikan melainkan dikonsumsi sendiri. Berdasarkan wawancara dengan salah satu warga desa Tapen dan juga Kepala Desa Tapen, hal ini disebabkan karena edukasi tentang pengolahan dan pemasaran produk olahan ikan air tawar sangat minim. Masyarakat tidak memiliki inovasi dalam mengolah ikan untuk dijual, sehingga masyarakat hanya mampu menjual ikan segar tanpa diolah kepada konsumen.

Secara minoritas terdapat salah satu warga yang mengolah ikan hanya menjadi Rempeyek Ikan Asin. Hasil observasi lapangan dan wawancara menunjukkan usaha pengolahan ikan tersebut menghasilkan keuntungan yang lebih besar dibandingkan jika ikan tersebut dijual segar. Namun demikian, rata-rata tingkat pendapatan yang diperoleh masih rendah. Terdapat aspek permasalahan yang dihadapi masyarakat yaitu produksi dan manajemen. Pada aspek produksi terdapat permasalahan utama yang berkaitan dengan penanganan olahan ikan yaitu jenis produk olahan ikan yang kurang beragam, dan penanganan terhadap produk olahan yang sudah dihasilkan masih sangat sederhana, belum dilakukan pengemasan dan pelabelan produk yang baik serta tidak memiliki legalitas keamanan produknya. Sedangkan permasalahan pada aspek manajemen adalah terbatasnya pengetahuan tentang ragam jenis olahan ikan, range harga dan pemasaran yang berpengaruh pada mutu produk olahan ikan yang dihasilkan belum seragam, kontinuitas belum dapat terpenuhi dan jangkauan pemasaran masih terbatas.

Berdasarkan permasalahan di atas, maka terdapat beberapa solusi yang ditawarkan pada kegiatan

KKN BBM ini. Berkaitan dengan permasalahan pada aspek produksi yaitu kurang beragamnya produk olahan ikan yang dihasilkan, maka solusi yang ditawarkan adalah diversifikasi produk olahan ikan atau menganekaragamkan produk olahan ikan air tawar. Menurut Wardani et al. (2010), produk olahan ikan memberikan gambaran yang lebih menguntungkan daripada produk ikan segar seperti adanya berbagai variasi bentuk dan ukuran produk, jumlah produk sedikit dan menghemat tempat, produk umumnya tahan lama dan jenis olahan selalu sama sesuai permintaan.

Pada kegiatan ini produk olahan ikan yang dipilih untuk disosialisasikan kepada masyarakat Desa Tapen khususnya masyarakat Dusun Jatian adalah keripik ikan wader, nugget ikan nila, dan siomay ikan lele. dengan bahan baku ikan air tawar yang banyak ditangkap nelayan dari Sungai Sampean Baru dan Danau Bendungan Sampean Baru yang berada di sekitar Desa Tapen. Ada beberapa pertimbangan pemilihan keripik ikan wader sebagai solusi produk yang ditawarkan yaitu: (1) Keripik Wader sudah dikenal oleh orang banyak, (2) Pengolahannya sangat mudah, sehingga dapat dipahami dan dilakukan oleh masyarakat dengan tingkat pendidikan rendah, (3) Modal pengolahannya tidak besar dan bahan pembuatannya juga mudah diperoleh, (4) Produk olahan yang tahan lama (Ernawati \& Wulandari, 2013).

Bentuk olahan lainnya sebagai solusi yang ditawarkan adalah nugget ikan nila dan siomay ikan lele. Nugget merupakan salah satu produk olahan daging ikan giling dan diberi bumbu serta dicampur atau ditambahkan bahan pengikat kemudian dicetak menjadi bentuk - bentuk tertentu, selanjutnya dilumuri tepung roti atau panir sebagai pelapis kemudian digoreng. (Syamsir, 2008). Umumnya masyarakat di Desa Tapen mengenal nugget yang berbahan daging sapi dan daging ayam. Produk nugget ikan 
diyakini juga dapat menjadi alternatif produk olahan ikan karena proses pengolahannya dan cara perolehan bahan bakunya mudah. Sedangkan siomay ikan adalah adonan ikan yang dipadu dengan tepung dan memiliki rasa gurih. Bahan dasarnya tidak hanya dari ikan laut, melainkan ikan tawar juga dapat dijadikan bahan dasar seperti ikan lele, ikan nila, ikan patin, dan lain-lain. Optimalisasi tujuan kegiatan KKN BBM Kelompok 60 diwujudkan melalui sosialisasi pengolahan dan pemasaran produk olahan bahan asal ikan dengan melakukan demonstrasi bersama masyarakat Desa Tapen.

Adapun tujuan dari kegiatan KKN BBM Kelompok 60 ini adalah (1) Menghasilkan diversifikasi produk olahan ikan berupa keripik ikan wader, nugget ikan nila, dan siomay ikan lele berbahan baku ikan yang ada di sungai dan danau Bendungan Sampean Baru. (2). Meningkatkan pengetahuan dan keterampilan dari masyarakat desa Tapen khususnya di dusun Jatian tentang pembuatan desain kemasan, pelabelan dan perijinan produk serta mengatur keuangan, analisis usaha sederhana, strategi produksi dan pemasaran serta menggunakan media sosial dan marketplace sebagai bentuk pemasaran yang efektif di masa pandemik Covid-19. (3). Meningkatkan pendapatan penduduk Desa Tapen khususnya masyarakat yang ada di Dusun Jatian yang sering menangkap ikan di sungai dan danau Bendungan Sampean Baru.

\section{METODE PENGABDIAN MASYARAKAT}

Adanya pandemi Covid-19 menyebabkan dunia harus menjalankan kehidupan adaptasi kebiasaan baru. Segala bentuk kegiatan yang dilakukan harus mematuhi dan mempertimbangkan protokol kesehatan sebagai tindakan pencegahan penularan Covid19, termasuk sistem pendidikan di Indonesia. Hal tersebut menyebabkan perguruan tinggi harus melakukan metode pembelajaran jarak jauh secara Blended/ Hybrid demi mendukung pencegahan penularan Covid-19 tersebut. Tidak terkecuali dengan program Kuliah Kerja Nyata $(\mathrm{KKN})$ yang setiap semester rutin dilaksanakan oleh mahasiswa perguruan tinggi pun harus dilaksanakan secara Blended/ Hybrid.

Dalam menyukseskan pelaksanaan Kuliah Kerja Nyata (KKN) Ke 63 Universitas Airlangga, kelompok 60 mengunggulkan program kerja „Sosialisasi Pengolahan dan Pemasaran Produk Olahan Asal Ikan" dalam upaya meningkatkan pendapatan masyarakat setempat terhadap perekonomian di Desa Tapen Kecamatan Tapen Kabupaten Bondowoso dengan sasaran ibu-ibu PKK, ibu-ibu Nelayan, dan calon pengusaha. Terdapat intervensi yang kami lakukan secara dalam jaringan (daring) dan intervensi secara luar jaringan (luring). Intervensi yang kami lakukan secara daring berupa diskusi-diskusi terkonsep dalam kelompok yang dikirim melalui platform media grup Whatsapp, selain itu peserta kelompok 60 memberikan penjelasan singkat melalui fitur voice notes terkait hal-hal strategi pemasaran di era Pandemi Covid-19. Sedangkan untuk intervensi yang dilakukan secara luar jaringan (luring), peserta kelompok 60 mengadakan demonstrasi secara langsung kepada ibu-ibu PKK, ibu-ibu nelayan dan calon pengusaha tentang bagaimana cara mengolah dan memasarkan produk olahan asal ikan sebagai peluang bisnis masyarakat di dusun Jatian, Desa Tapen, Kecamatan Tapen, Kabupaten Bondowoso. Selain itu, peserta kelompok 60 memberikan lembaran pretest-postest, guna mengetahui pengetahuan masyarakat tentang pengolahan dan pemasaran produk olahan ikan seperti keripik ikan wader, nugget ikan nila, dan siomay ikan lele. Lembar pretest- postest dibagikan kepada 15 orang yang terdiri dari ibu-ibu kader dusun Jatian, ibu-ibu kader dusun Jesaba, dan ibuibu dari istri nelayan. 


\section{HASIL DAN PEMBAHASAN}

Kegiatan kuliah kerja nyata belajar bersama masyarakat dilaksanakan pada tanggal 6 Februari 2021 di Cafe Wisata Bukit Luwih. Adapun bentuk kegiatan pada kegiatan sosialisasi ini terdiri dari 6 tahapan, yaitu tahapan persiapan kegiatan, pengisian kuesioner pretest, tahapan penyuluhan dengan presentasi oleh Ketua dan Sekretaris kelompok 60, tahapan demonstrasi atau peragaan dilakukan oleh anggota kelompok $60 \mathrm{KKN}$, serta tahapan diskusi yang dilakukan antara masyarakat dan semua anggota kelompok 60 dan yang terakhir tahapan pengisian kuesioner post test. Setiap peserta yang hadir mendapatkan contoh produk pengolahan keripik ikan wader, nugget ikan nila, dan siomay ikan lele yang telah disiapkan oleh Tim kelompok 60 kepada masyarakat.

\section{Persiapan Kegiatan}

Kegiatan persiapan pertama yang dilakukan adalah penentuan lokasi kegiatan Kuliah Kerja Nyata Belajar Bersama Masyarakat (KKN-BBM) sosialisasi pengolahan dan pemasaran produk olahan ikan air tawar, praktik dan pembagian hasil olahan keripik ikan wader, nugget ikan nila, dan siomay ikan lele. Penentuan lokasi kegiatan didiskusikan bersama Ibu Kepala Desa Tapen. Berdasarkan hasil diskusi bersama Ibu Kepala Desa bahwa kegiatan ini akan dilaksanakan di Cafe Wisata Bukit Luwih pada hari Jumat, 5 Februari 2021 Pukul 19.00 WIB. Akan tetapi, perencanaan tidak sesuai dengan realitas. Bahwasanya pada hari Jumat terdapat kendala hujan deras yang dihadapi oleh peserta KKN sehingga warga masyarakat yang diundang berhalangan untuk hadir. Berdasarkan keadaan dan situasi yang dihadapi, peserta KKN menunda pelaksanaan kegiatan sosialisasi tersebut pada keesokan harinya yaitu hari Sabtu, 6 Februari 2021 Pukul

08.00 WIB.

\section{Pengisian Kuesioner Pretest}

Sebelum acara sosialisasi pengolahan dan pemasaran produk olahan ikan air tawar kepada seluruh masyarakat, kami membagikan kuesioner pretest yang terdiri dari 8 pertanyaan yaitu: (1) Apakah Anda mengetahui kandungan gizi ikan ?, (2) Apakah Anda mengetahui jenis-jenis produk olahan ikan seperti Nugget ikan dan cara pembuatannya?, (3) Apakah Anda mengetahui jenis-jenis produk olahan ikan seperti Siomay ikan dan cara pembuatannya?, (4) Apakah Anda mengetahui jenis-jenis produk olahan ikan seperti Keripik ikan Wader dan cara pembuatannya ?, (5) Apakah Anda mengetahui bagaimana cara mengolah ikan tanpa mengurangi kandungan gizi ikan ?, (6) Apakah Anda mengetahui bagaimana cara menjual produk olahan ikan ?, (7) Menurut Anda, apabila terdapat sosialisasi tentang pengolahan dan pemasaran produk olahan ikan, apakah Anda bersedia ingin memulai usaha ? dan 1 pertanyaan mengenai alasan masyarakat tidak ingin memulai usaha. Hasil kumulatif yang diperoleh tertera pada tabel berikut:

Tabel I Tingkat Pengetahuan Masyarakat

\section{No. Tingkat pengtahuan}

\section{Frekuensi Persentase}

\begin{tabular}{l|c|c|c}
\hline $\mathbf{1}$ & Rendah & 9 & $60 \%$ \\
$\mathbf{2}$ & Sedang & 0 & $0 \%$ \\
$\mathbf{3}$ & Tinggi & 6 & $40 \%$ \\
\cline { 2 - 3 } & &
\end{tabular}




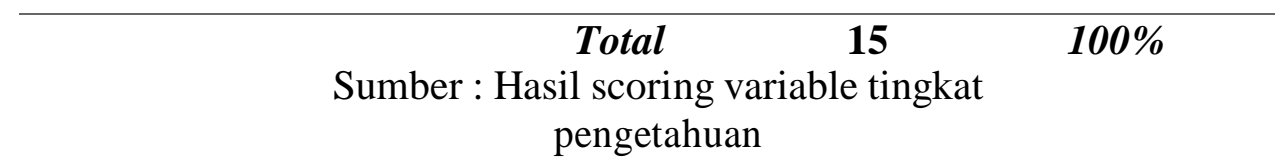

Berdasarkan tabel diatas dapat diketahui bahwa tingkat variable dari 15 responden yang mengisi kuesioner didapatkan sebanyak $60 \%$ responden berada pada posisi rendah mengenai pengetahuan tentang pengolahan dan pemasaran produk olahan ikan air tawar, dan sisanya sebanyak $40 \%$ responden yang memiliki tingkat pengetahuannya tinggi.

\section{Pelaksanaan Sosialisasi Pengolahan dan Pemasaran Produk Olahan Ikan Air Tawar}

Kegiatan Kuliah Kerja Nyata Belajar Bersama Masyarakat "Sosialisasi

Pengolahan dan Pemasaran

Produk Olahan Ikan Air Tawar" telah dilaksanakan pada hari Sabtu, 6 Februari 2021 dari pukul $08.00-10.00$

WIB. Kegiatan diikuti oleh 22 orang yang terdiri dari Bapak Sekretaris Desa, 5 kasun (Kasun Jatian, Kasun Bunutan, Kasun Posong, Kasun Jesabe, Kasun Krajan), Kepala Babinsa Desa Tapen, dan 12 orang masyarakat dusun Jatian, 3 orang masyarakat dusun Jesaba. Secara umum kegiatan sosialisasi pengolahan dan pemasaran produk olahan ikan air tawar dengan cara persentase oleh ketua dan sekretaris kelompok 60 tentang kandungan gizi yang dimiliki oleh ikan, dan cara mengolah serta memasarkan produk olahan ikan air tawar sebagai upaya meningkatkan pendapatan masyarakat desa setempat (Gambar 1).

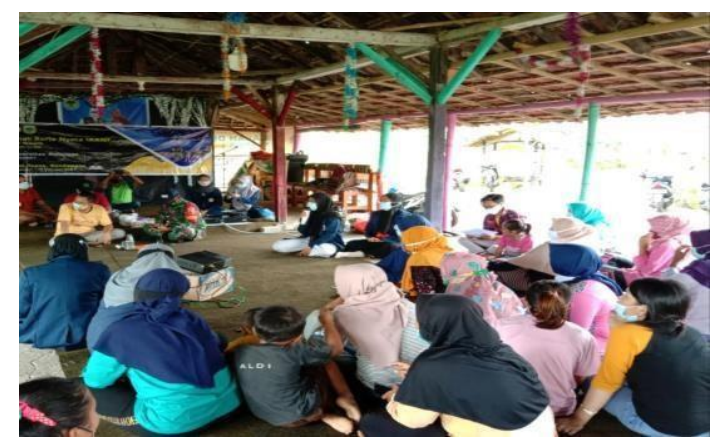

Gambar 1. Pelaksanaan Kegiatan Sosialisasi Pengolahan dan Pemasaran Produk Olahan Ikan Air Tawar

Pada tahap ini dilakukan dengan ceramah atau penyuluhan tentang diversifikasi pengolahan ikan dalam bentuk keripik ikan wader, nugget ikan, dan siomay ikan. Selanjutnya menjelaskan tentang cara memasarkan produk di marketplace sebagai tindakan yang paling efektif di masa pandemik Covid 19. Pada tahap kegiatan ceramah ini masyarakat terlihat aktif yang ditunjukkan dengan beberapa pertanyaan dari peserta. Pertanyaan itu antara lain: Jenis ikan yang digunakan untuk pembuatan Nugget Ikan dan Siomay Ikan, Berapa lama proses pengukusan Nugget Ikan dan Siomay Ikan, Bagaimana cara memasarkan produk di salah satu marketplace seperti Shopee, Berapa lama daya simpan produk Keripik Ikan Wader, Nugget Ikan dan Siomay Ikan, Bagaimana cara mengolah ikan yang benar tanpa mengurangi kandungan gizi yang ada di dalam ikan

Tahap selanjutnya diberikan materi tentang pelabelan, dan cara memasarkan produk di marketplace. 
Pelabelan adalah informasi yang dapat ditampilkan melalui kemasan (Widadi Padmarsari, dkk, 2018: 304). Beberapa informasi yang dapat disampaikan melalui kemasan antara lain adalah: Nama produk, Nama Produsen, Alamat produksi dan telepon yang bisa dihubungi, Komposisi, Kandungan gizi, Cara penggunaan, Kontra indikasi, Tanggal kadaluwarsa, Nomor produksi.

\section{Demonstrasi atau Peragaan Pembuatan Produk Olahan Ikan dan Pembagiannya}

Tahap selanjutnya ialah peragaan dan praktik pengolahan keripik ikan wader, nugget ikan dan siomay ikan. Kegiatan ini bertujuan untuk meningkatkan pengetahuan masyarakat tentang kandungan gizi ikan, cara mengolahnya dengan benar tanpa mengurangi kandungan gizi ikan tersebut, dan dapat membuka peluang usaha bagi masyarakat di tengah pandemik Covid-19. Kegiatan ini sekaligus membagikan contoh produk olahan ikan dan dengan harapan ibu-ibu bisa membuatnya di rumah masingmasing serta memulai usaha produk olahan ikan air tawar (Gambar 3).

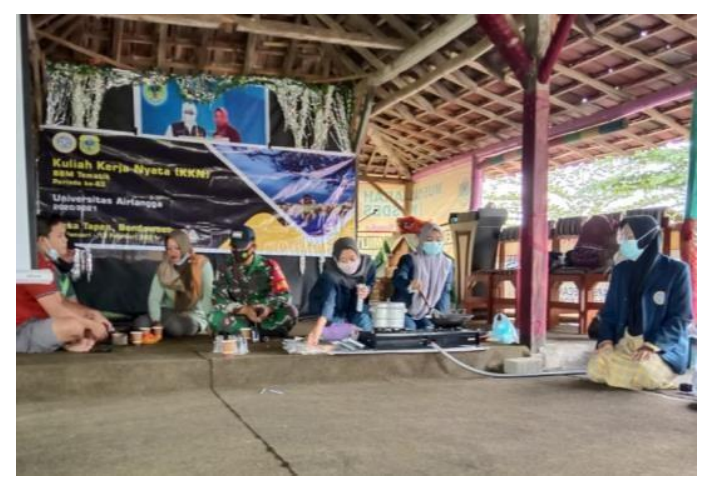

Gambar 2. Demonstrasi atau peragaan pembuatan produk olahan ikan

\section{Pengisian Kuesioner \\ Post Test}

Setelah acara sosialisasi pengolahan dan pemasaran produk olahan ikan air tawar kepada seluruh masyarakat, kami membagikan kuesioner post-test dengan pertanyaan yang sama. Hasil dari pertanyaan terkait kesediaan masyarakat dalam memulai usaha setelah mendapatkan sosialisasi tentang pengolahan dan pemasaran produk olahan ikan tertara pada tabel berikut:

Tabel II Kesediaan Memulai Usaha

$\begin{array}{ccc}\text { No. Kesediaan } & \text { Frekuensi } & \text { Persentase } \\ \text { Memulai } & \\ \text { Usaha } & \end{array}$




\begin{tabular}{cc|c|c}
\cline { 2 - 4 } $\boldsymbol{1} 2$ & Ya. Bersedia & 9 & $60 \%$ \\
\cline { 2 - 4 } & Tidak Bersedia & 6 & $40 \%$ \\
\hline \multicolumn{2}{c}{ Total } & $\mathbf{1 5}$ & $\mathbf{1 0 0 \%}$ \\
\multicolumn{2}{c}{ Sumber : Pertanyaan No.12, koding 11}
\end{tabular}

Berdasarkan dari data tabel II pada pertanyaan terkait kesediaan masyarakat dalam memulai usaha setelah mendapatkan sosialisasi tentang pengolahan dan pemasaran produk olahan ikan, didapatkan sebanyak $60 \%$ responden menjawab Ya Bersedia, dan sebanyak $40 \%$ responden menjawab tidak bersedia. Dari responden yang menjawab tidak bersedia dalam memulai usaha terdapat beberapa alasan yang disebutkan oleh responden, diantaranya ialah alasan tidak memiliki modal, alasan tidak memiliki waktu dan alasan tidak memiliki keberanian dalam berusaha. Hal ini juga menjadi hambatan bagi masyarakat dalam memulai usaha ditengah pandemik Covid-19.

\section{PENUTUP}

Simpulan

Kegiatan KKN di Desa Tapen Kecamatan Tapen Kabupaten Bondowoso selama Januari hingga

Februari 2021 telah berhasil dilaksanakan. Kegiatan KKN menggunakan metode blended yaitu mencampurkan antara kegiatan yang bersifat luring dan daring. Salah satu kegiatan yang bersifat luring adalah Sosialisasi Pengolahan dan Pemasaran Produk Olahan Ikan Air Tawar guna meningkatkan pendapatan masyarakat di Desa Tapen Kecamatan Tapen Kabupaten Bondowoso. Sosialisasi berisi presentasi mengenai macam-macam dan kandungan gizi pada ikan air tawar, contoh produk olahan ikan dan cara pemasaran secara luring dan daring kepada masyarakat. selanjutnya kegiatan diisi dengan demonstrasi cara pengolahan produk ikan air tawar berupa siomay yang terbuat dari ikan lele serta nugget yang terbuat dari ikan nila. Kegiatan diawali dan diakhiri dengan pengisian pretest dan post-test guna menjadi indikator pemahaman masyarakat yang mengikuti kegiatan sosialisasi.

Saran

Kepada tim pengabdian masyarakat seluruh Indonesia diharapkan akan ada banyak lagi program kerja pengabdian mengenai strategi branding UMKM khususnya di masyarakat pedesaan seluruh Indonesia. Kami merasa bahwa pengabdian kami pada masyarakat dusun Jatian Desa Tapen perlu ditindaklanjutkan dengan waktu yang lebih panjang. Hal ini karena masyarakat dusun Jatian Desa Tapen masih perlu edukasi yang banyak mengenai diversifikasi pengolahan produk bahan asal ikan dan juga strategi pemasaran yang tepat. Kepada pemerintah diharapkan dapat memberikan perhatian khusus serta membuat perubahan-perubahan yang mampu membantu secara efektif kehidupan masyarakat dusun Jatian Desa Tapen sesuai dengan potensi sumber daya alam yang dimiliki desa tersebut. Kepada pembaca diharapkan dapat menyadari akan potensi yang berada di sekitar desa Tapen dan membantu memberikan inovasi guna meningkatkan penghasilan masyarakat di desa setempat.

\section{DAFTAR PUSTAKA}

Belitz H.D, G Werner, P. Schieberle. (2009). Food Chemistry. 4th. Springer Berin.Berlin 
Ernawati A.T.D, A.Wulandari. (2013). "Uji Kimia Keripik Kulit Ikan patin (Pangasius pangasius) dengan Perbedaan Perlakuan Suhu Perendaman”. Magistra Th XXV No. 83

Hazmi, A., Yulinda, E., Hendri, R. (2019). “Optimalisasi Pemanfaatan Media Sosial Untuk Meningkatkan Pemasaran Produk Olahan Ikan di Desa Hangtuah Kabuaten Kampar Provinsi Riau". Journal of Rural and Urban Community Enpowerment.

Indriyani, Wulansari D, Mursyid, Rahmi S.L, Rahmayani I. (2020). "Pemanfaatan Hasil Perikanan Dalam Bentuk Olahan Daging Ikan Nila Menjadi Nugget Dalam Rangka Diversifikasi Pangan pada Warga RT 07 Desa Kedotan, Kecamatan Sekarnan, Kabupaten Muaro Jambi”. Jurnal Karya Abadi Vol 4 (3).

Kurniawati A, Mustikasari D, Kresnasari D. (2019). "Pembuatan Nugget Ikan (Fish Nugget) Sebagai Salah Satu Usaha Deferensiasi Pengolahan Ikan di Sekolah Alam Banyu Belik". Cendekia: Jurnal Pengabdian Masyarakat. Vol 1 (2).

Syamsir, E. 2008. Membuat Nugget Ikan. http://Ilmupangan.Blogspot.Com. [Akses : 7 Februari $2021: 10.41]$.

Wardhani, R.M, Indah R.P, Indayati. (2010). "Peningkatan Pendapatan Masyarakat Melalui Diversifikasi Produk Olahan Ikan”. Agritek. Vol 11 (2): 54-63.

Yudaswara, R. A., Rizal, A., Pratama, R. I., \& Suryana, A. A. H. (2018). “Analisis kelayakan usaha produk olahan berbahan baku ikan nila (Oreochromis niloticus)(Studi Kasus di CV Sakana Indo Prima Kota Depok)". Jurnal Perikanan Kelautan, 9(1). 